\title{
The Role of Literature in the Institutionalisation of the National Standard Language
}

\author{
Asime Feraj \\ PhD Candidate, Vlorë \\ Email: asimeferaj@gmail.com
}

\section{Doi:10.5901/jesr.2013.v3n7p460}

\begin{abstract}
In this paper is treated the relation between the language and the literature and the ways to purify and enrich it. The language of the artistic literature is the largest and most diversified version of our national language. The artistic literature has the possibility to give support to raise the Albanian language as the language of all Albanians, to spread the unified and common language, to cultivate and purify it.On the ways of enrichment and purifying of the Albanian language I have emphasized the foundation on the popular language and on the old authors as inexhaustible sources for the enrichment of the artistic literature language with strong stylistic effects, but even the possibility to substitute the foreign words. The paper is based on a rich literature, studies of the our well known linguists, but even on the youngest researchers that have brought values on the linguistic field. Although in the paper will take place collects from the language of Fatos Arapi composition.
\end{abstract}

Keyword: national language, artistic literature language, relation between language and literature, purifying and enrichment of the language.

\section{Language and literature}

For a writer the word is the raw material for a literary work. This fact is also observed in the definition of literature as the "art of the word". There can be no literature without words, without language. This close relationship between literature and language appears in all dimensions, both in the dimension of literature writing and the theoretical one, i.e. the disciplines treating these two phenomena.

From this viewpoint, the writer must show greater attention and responsibility towards the national standard language. This means that:

1. Literature should penetrate into the deepest layers of the people's treasure and process it thoroughly, the same way it does with the poetic ideas, because language for literature merges with the content just as the marble transforms into a statue. (Kostallari 1989)

2. It is time for literature to provide a great contribution to the enrichment and elimination of unnecessary foreign linguistic constructions in Albanian language.

Language in literature is used above all as a means of performing the aesthetic function and it is part of the national standard language. However, language in literature represents the highest degree of development of the language of people, because literature is the art of the word and it exerts a considerable influence on readers. The language of literature stays deep in their heart and mind, enriches and ennobles them spiritually, but above all, it makes their love of mother tongue grow stronger.

The language of literature constitutes the broadest and most diverse style or variety of our national standard language. Moreover, it has the greatest possibility to remain in the domain of the people's language, to be nourished by it and at the same time to be closely related with the tradition of the standard language, because the vitality and power of a language is stronger and long-lasting in literature than in any other field.

Literature has a great potential to give its contribution to the spread of standard and common language as well as to its cultivation and enrichment. Writers, as indefatigable masters of language, as word-makers, inventors, hunters and researchers of words, have provided language with words and expressions of the popular stock which were not previously known. The history of the language in relation to the greatest languages of the time, Latin, Greek, Turkish and Slavic, has made loanwords so numerous in the lexicon that Albanian lost many of its old words.

Moreover, we should take into account the absence of an Albanian state and a public administration which would initiate the establishment of a common official standard language for all Albanians.

The need for a common language has been observed in the earliest writings in Albanian: "Meshari" by Gjon 
Buzuku (1555), "E mbësueme e krishterë" by Lekë Matrënga (1592). As translations of religious instruction into Albanian language from Latin liturgy, they accomplish a religious mission, but both authors thought they were laying the foundations of a written language not only for their place of birth but for the Albanian nation as a whole too. This is the national and cultural value of their works (Gjinari 2003) along with the concern about avoiding the deterioration and of our language. This role was to be played by literature and our old and new writers.

\section{Ways to purify and enrich Albanian language}

One of the ways to enrich and purify language is by reviving the lexicon of old literature. Many words of old authors have been lost and are out of use, but a number of them can be used in certain styles of standard language, literature in particular, to convey a new meaning or shade of meaning. For example:

frutoj "fruit", i frutueshëm, i pafrut Budi; i pafrutuar, frutues dhe frutesë (producing fruit) Bardhi; arrëtoj "invent, make up" arrëti, arrëtim, arrëtues; shtatpëlqyer "midget", tridhambësh "hayfork", mjalcë "bee", Bardhi; zemërkëmbyem "coward", therëcë "thorny bush", bamir Buzuku; kryekërcyem "anger", i papasur "poor", i pafaqe, dritëzë "lantern", binosh "twins", ndërkamb "override", akulloj "freeze", akullohem "my heart breaks" Bogdani (Sinani-Bulo 1989)

With the suffix -tar: peshkatar, gojëtar "lawyer" Buzuku; fjalëtar "articulate speaker", pajëtar "assistant", Kuvendi i Arbrit; kundërtar Bardhi; arrëtues "inventor", manesë "delay", trajtoj "build" Kristoforidhi;

With the suffix - (e)zë: hiezë "umbrella", bamezë "deed", krefezë "trap" Bardhi

Adjectives of negative meaning, with prepositive article, with the prefix pa -:

i paurtë "not correct" Buzuku; i padëlirë Budi; i padashur "ungrateful" Bogdani

Kristoforidhi endeavored to revive some of the words of the old authors in his writing and some of these words were used in the literature of the Renaissance. Some of the words we use today, such as dëftues, grykës, këngëtar, detar, këshilltar, madhështi, trajtim, shkollor, kundërshtar date back to the old authors. (Arapi 1989)

The linguistic movement for the purification of our language was consolidated by our Renaissance representatives with the aim of establishing a national standard language. The precursor of these efforts, N. Bredhi - Veqilharxhi set four basic requirements: (Lafe 1989)

1. The purification and enrichment of the language must be viewed as a single task and "you should not only use language but also enrich it"

2. Foreign words should be substituted with words of Albanian stock.

3. This initiative is just the first step and it should be taken further by the next generations.

\section{Neologisms in the works of Fatos Arapi}

This study also elaborates on a part of the vocabulary used in the literary works of F. Arapi, one of the most renowned Albanian writers, whose language has drawn the attention of Albanian linguists but it has been treated too little so far. I have mostly focused on word-formation as the author has a deep understanding of the lexical and semantic resources of Albanian language in general and the region of Labëria in particular. He uses these resources elegantly by being aware of the fact that dialectal words can be potentially absorbed by the standard language and they can perform diverse expressive functions. Moreover, the writer enriches Albanian language with new linguistic units from the Albanian stock of words, and this can be considered the greatest contribution of the author. The examples used here are just a part of the numerous lexical resources and they are used to illustrate the statement made above but other papers will elaborate on this topic. This study includes neologisms used in the literary works of F. Arapi, which are not part of the F.GJ.S.SH. (1980).

Let us consider the following groups:

\subsection{Words formed by affixation}

The formation of new words by using affixes (prefixes and suffixes) is the most productive form in Albanian language. Words formed by prefixation are fewer than those formed by suffixation because the number of prefixes in Albanian is smaller than the number of suffixes (68-170). Nevertheless, the books of F. Arapi show the opposite, more new words formed by prefixation. 


\subsubsection{Words formed by prefixation}

As regards prefixation, special attention is paid to words of denotative and stylistic value with the prefixes: për- $\boldsymbol{i}$ përzhitur përvidhet, përgjunjet, përfaluni, të përhimtë, përvëlonjëse,

Për- : is used as a prefix to form nouns, adjectives, verbs and adverbs

With emphatic meaning: flokë të përhimtë, me ngjyrë të hirtë, a synonym of the word të thinjur.

përgjumet. A state of sloth. The need and desire to sleep. Being unprepared for unexpected events and risks.

With the sense of action (for verbs formed by nominal stems) përgjunjet. Give in; përçmoj. Not appreciate somebody or something. With the opposite meaning of the respective word without this prefix; përvidhet. Leave secretely; përfaluni. Respect, honor; përzhitur. Burnt partly; gjuhët përvëlonjëse. Poignant. Pejorative figurative meaning.

Pa- prefix. It is used to form nouns and adjectives with the opposite meaning of the word: sytë e padritë, ëndërr $e$ paëndërruar, të paqena, i padrojtur, pashpresa,

The prefix pa- is added not only to adjectivized participles to form their antonyms, such as ëndërr e paëndërruar, të paqena, but also to nominal stems, and we still obtain adjectives: të paemrit, sytë e padritë

Porsa- It is used as the first part of words formed by the stem of participial adjectives, with the meaning of "something which has just happened or been done, ex. porsa: i porsazgjuar, të porsagufuara, ...

Prefixation does not generally result in a change of the lexical-grammatical category of the word. The new word belongs to the same part of speech as the stem of the word it derived from. For example, the stems of the nouns: dritë, ëndërr, ... have produced nouns; the stems of the adjectives: $i$ drojtur, të hirtë, $i$ zgjuar, $i$ gufuar have produced the adjectives: i padrojtur, të përhimtë, i porsazgjuar, i porsagufuar ; the stems of the verbs vidhet, falet, vëloj, çmoj have produced the verbs: përvidhet, përfalet, përçmues, përvëlonj

However, there are cases when the lexical-grammatical category changes in Albanian. For example, the verbs: përgjumet, përgjunjet, have derived from the nominal stems gjumë, gju. The adjectives e padritë,e paëndërruar, të paqena, të përzhitur have derived from the nominal stems dritë, ëndërr and the participles of the verbs ëndërroj, jam, përzhit.

\subsubsection{Words formed by suffixation}

One of the most common suffixes is the diminutive one, -zë, such as: rrëmbezë "i vë gjoksin rrëmbezës", small water canal; çupëz "çupëz moj fluturëz prej bore", arkëz "Ja dhe gjyshja në arkëz", kartëz "Kukull e vogël në kartëz" këmbëzat " këmbëzat e çitjaneve nuk ngjiteshin lart"; lakëzat "arrinin gjer te lakëzat e pulpave"; cazë "cazë bizantinë, cazë otomanë"

-AR,thinjar/ i, m. From thinjosh, -e adj. One whose hair has gone grey or has grey hairs. Neutral meaning. As a noun with pejorative, contemptuous connotation.

gërnjar adj. Someone who talks too much. Mos ki frikë prej atij thinjari gërnjar. From Gërg/askal.,fig. Bother someone time and time again.

\subsection{Words formed by compounding}

Compound words convey a highly positive or negative emotional value, bearing characteristics of the elevated style, and are generally based on comparison with familiar things or phenomena. Compound words are formed by joining two stems, either nominal, adjectival, verbal or adverbial. Let us consider the following examples:

Gjysmë is used as the first part of compound words whose meaning is 1. Half of something; gjysmëhënat, 2. Përgjysmë; to some extent, not completely, not to the end; gjysmanalfabete, gjysmëndrre, gjysmëmëshirë, gjysmëbrenge, gjysmëfati, gjysmëputhje, gjysmëfantazmat, gjysmëvdekur, gjysmëgjallë

Krye-: kryekrushk/ $u \sim m$. From colloquial speech, the main person, the one staying in the front, leading the wedding participants.

kryeulur adj. Synonym of kokulur; kryeatdheu; kryekuvend fig. More honored; better.

trup: truplartë synonym of shtatëlartë

buzëngjyer adj. It is used with the same meaning as Buzëkuq, adj.n. Whose lips are red; negative connotation.

Buzëmbrëmjes. In F.GFJ.S.SH. we find the example: Buzë mbrëmjes (muzgut). F. Arapi uses it as a single word: buzëmbrëmjes, see Buzë-preposition. On the verge of something, at the beginning of an event (used with a noun in the ablative case). 
F. Arapi uses neologisms which consist of two derivational stems, such as: burra zemërdielli, nëpër bedenat e dhëmbëdhëmballëve të tij të rëna, në këngëgjëmimin e përjetshëm të gjakut, mbyt lotin jetëvrarë, yjet pullaflakëruese, shkëmbguriçkë, ballëvrenjtur, rini ëndërrpavdekshme, shoqedhembshura ime, fytyrdrobitur, fatthëna, durbuavitur, zorrëthatë etc.

I. A more detailed analysis of these words shows that the relationships between these stems are diverse. There are compound words in which one member determines the other. There are attributive compounds and in some compound words the members are equivalent and determine each other. These are compounds of coordination.

This study shows that the number of attributive compounds is greater than the number of compounds of coordination.

Attributive compounds: The second member determines the first one: zemërdielli- zemër si dielli; jetëvrarë jetë e vrarë; ballëvrenjtur - ballë i vrenjtur; ëndërrpavdekshme - ëndërr e pavdekshme; shoqedhembshura shoqe e dhembshur; fytyrdrobitur - fytyrë e drobitur; durbuavitur - dur të buavitura; zorrëthatë - zorrë e thatë; fatthëna - fat $i$ thënë.

The first member determines the second one: këngëgjëmimin - gjëmimin e këngëve;

Compounds of coordination: There are fewer words of coordination: dhëmbëdhëmballëve - dhëmbë $e$ dhëmballë,

II. Another classification of compound words can be made in terms of the lexical-grammatical value:

Nominal: kryekrushk, këngëgjëmimin, kryeatdheu, kryekuvend, shoqedhembshur,

Adjectival: zemërdielli, ëndërrpavdekshme, shoqedhembshura, fytyrdrobitur, fatthëna, durbuavitur, zorrëthatë, gjysmëvdekur, gjysmëmëshirë, jetëvrarë,

Adverbial: buzëmbrëmjes, gjysmëvdekur, ballëvrenjtur,

III. Compound words can also be grouped according to the way they are formed in terms of the lexicalgrammatical value of the members:

Noun+noun: kryeatdheu, kryekuvend, gjysmëhënat, këngëgjëmimin, gjysmëmëshirë, gjysmëbrenge, gjysmëfati, gjysmëputhje, gjysmëfantazmat, zemërdielli, këngëgjëmimin

Noun+adjective: gjysmëvdekur, gjysmëgjallë, kryeulur, buzëngjyer, jetëvrarë, ballëvrenjtur, ëndërrpavdekshme, shoqedhembshura, fytyrdrobitur, fatthëna, durbuavitur, zorrëthatë.

These various classifications of compound words are important because the meaning of the unit as a whole is clarified by using different approaches.

\section{Conclusions}

1. Language is the most important tool for the writer. It is the basic means of form, communication, plot, ideas and opinions of the literary work. Therefore, the enhancement of the artistic value should be accompanied by increased attention to language on the part of the author. (Dilaveri 1989)

2. Literature is a creative and language-cultivating discipline. It serves the linguistic education of generations and should do its best to meet this requirement. We should take into consideration the fact that there is no good literature without good language.

We cannot speak of a national language and at the same time forget that the norm is its central axis. (Kostallari 1989)

3. The national language serves the whole nation and is actively mastered by the overwhelming majority of the population, especially in its written form. The written form is the common element of the unitary language. The acquisition of its system can be achieved through its institutions, its educational institutions, and it can be supported and enhanced by literature because the most renowned writers, with their linguistic abilities and qualitative literary works, exert a direct and simultaneous influence on thousands of readers and users of Albanian language.

\section{References}

Arapi, Fatos. (1983) Poezi, Naim Frashëri, Tiranë.

Arapi, Fatos. (2002) Eklipsi i ëndrrës, Toena, Tiranë.

Arapi, Fatos. (1972) Dikush më buzëqeshte, Naim Frashëri, Tiranë.

Arapi, Ina. Gjallërimi i disa njësive leksikore të autorëve të vjetër për pasurimin e gjuhës së sotme letrare, in "Studime mbi leksikun dhe 
mbi formimin e fjalëve në gjuhën shqipe", III, Akademia E Shkencave E RPS Të Shqipërisë, Tiranë.

Dilaveri, Dilaver. (1989) Rreth përdorimit të arkaizmave leksikore në letërsinë artistike, in "Studime mbi leksikun dhe mbi formimin e fjalëve në gjuhën shqipe", III, Akademia E Shkencave E RPS Të Shqipërisë, Tiranë.

Gjinari, Jorgji . (2003) Dialektologjia, SHBLU, Tiranë.

Kostallari, Androkli. (1989) Gjuha letrare kombëtare shqipe dhe epoka jonë, in "Studime mbi leksikun dhe mbi formimin e fjalëve në gjuhën shqipe", III, Akademia E Shkencave E RPS Të Shqipërisë, Tiranë.

Lloshi, Xhevat. (2005) Stilistika dhe pragmatika, Albas, Tiranë.

Lafe, Emil. (1989) Lufta për pastërtinë e gjuhës në kohën tonë, in "Studime mbi leksikun dhe mbi formimin e fjalëve në gjuhën shqipe", III, Akademia E Shkencave E RPS Të Shqipërisë, Tiranë.

Memisha, Valter. (2011) Studime për fjalën shqipe, botart, Tiranë.

Sinani, A - Bulo, S. (1989) Visari i fjalëve dhe i shprehjeve popullore - burimi i madh për pasurimin e gj.l.k, in "Studime mbi leksikun dhe mbi formimin e fjalëve në gjuhën shqipe", III, Akademia E Shkencave E RPS Të Shqipërisë, Tiranë.

Shehu, Hajri. (1989) Rreth vlerave potenciale të leksikut popullor për gjuhën e sotme letrare shqipe, in "Studime mbi leksikun dhe mbi formimin e fjalëve në gjuhën shqipe", III, Akademia E Shkencave E RPS Të Shqipërisë,Tiranë. 